https://doi.org/10.31470/2706-7904-2020-15-303-307

\title{
ПСИХОЛОГО-КОМУНІКАТИВНИЙ ПОТЕНЦІАЛ НЕПРЯМОСПОНУКАЛЬНИХ ВИСЛОВЛЕНЬ
}

\section{Psychological and Communicative Potential of Indirect Incentive Utterances}

\author{
Vasyl Shynkaruk \\ DSc. in Philology, Professor \\ National University of Life and Environmental Sciences of Ukraine \\ vashyn2010@ukr.net \\ https://orcid.org/0000-0001-8589-4995 \\ Svitlana Kharchenko \\ DSc. in Philology, Associate Professor \\ National University of Life and Environmental Sciences of Ukraine \\ lucynka@ukr.net \\ https://orcid.org/0000-0001-9336-1259
}

\begin{abstract}
In the abstract the incentive is interpreted both as a psycholinguistic concept and a linguistic universal category; the components of the linguistic model and the functional structure of the incentive act are defined. The bidirection of the act of volition is emphasized. The volition (incentive) is identified as a kind of mental, speech activity, as a set of certain actions conditioned and motivated by the inner state of the speaker. The incentive action is aimed at meeting the communicators' needs and takes into account their interests. The example of vocative utterances shows how and under what conditions in specific communicative situations they are able to express an incentive modality. Linguistic means of enhancing the emotionally-expressive colouring of vocative utterances of incentive modality determined by the tasks of speech action are considered. It is established that the focus on the positive result of the incentive foresees the obligatory accounting of distinguished or assumed background knowledge, the usage of the single sign system for encoding and decoding information, conventions, communicative situation, etc.
\end{abstract}

Key words: incentive, psycholinguistic model, communicative situation, vocative utterance, incentive utterances. 


\section{Вступ}

Introduction

Дослідження граматичних явищ у психолінгвальному аспекті виявляють нові грані, адже описують мову як відображення концептуальної картини світу, ментальності нації тощо, де в процесі предметно-практичної та теоретичнопізнавальної діяльності взаємодіють комуніканти. Одним із засобом вербалізації такої взаємодії на синтаксичному рівні $\epsilon$ спонукальні висловлення, основною диференційною семантичною ознакою яких називають здатність виражати різновиди волевиявлення. І в українському, і в зарубіжному мовознавстві спонукальні (імперативні) висловлення ставали предметом лінгвістичних та психолінгвістичних досліджень, однак досі поза увагою науковців перебуває ситуативне сприйняття неспонукальних мовленнєвих одиниць як спонукальних. Тому задекларована тема актуальна.

Mema - описати психолінгвістичну модель акту волевиявлення в поєднанні 3 вивченням закономірностей функціонування мовленнєвої одиниці (на прикладі вокативних висловлень) в певному психолінгвальному просторі та їі інтерпретування адресатом.

\section{Методи та методики дослідження Methods and Techniques of the Research}

Специфіка досліджуваного предмета зумовила потребу використання низки методів: описового методу для визначення складників психолінгвістичної моделі акту волевиявлення i для розмежування видів спонукальних висловлень, методу класифікації - для інвентаризації й систематизації непрямоспонукальних висловлень, контекстуально-інтерпретаційного - для встановлення транспозиції неспонукальних висловлень у спонукальні в мовленнєвій діяльності, а також інтент-аналізу - для вивчення непрямоспонукальних висловлень, які в конкретній мовленнєвій ситуації адресат може інтерпретувати як спонукальні.

\section{Результати \\ Results}

Результативний цілеспрямований мовленнєвий вплив тільки тоді може бути ефективним, коли він «базується на чіткому уявленні про психологічні механізми впливу...» (Леонтьев, 1971: 10). 
Спонукальні висловлення найповніше i найвичерпніше виявляють своє категорійне значення в мовленнєвій діяльності, де родове значення конкретизується, зазнаючи різних семантичних модифікацій. Семантику спонукальних висловлень формують такі аспекти комунікативної діяльності, як волевиявлення i цілеспрямованість; вираження ірреального значення; особистісний; соціальний; психологічна близькість між комунікантами; ситуативність; обов'язкова адресованість. Усі названі аспекти містить психолінгвістична модель акту волевиявлення (спонукання). Спонукальний акт як «одиничний акт діяльності - це єдність усіх трьох їі складових: починається мотивом і планом, а завершується результатом, досягненням наміченої з самого початку мети; між ними - динамічна система конкретних дій та операцій, спрямованих на це досягнення» (Калмикова, 2007: 163). Акт волевиявлення двоспрямований.

Використовуючи спонукальні висловлення, виражені спеціалізованими засобами, мовець відкрито говорить про свій намір вплинути на когось чи щось. Використання ж неспеціалізованих спонукальних висловлень спрямовано на уникнення комунікативних помилок, конфліктності, агресивності. Активізація транспозиційних процесів у граматичних i семантико-синтаксичних значеннях відбувається передусім в усному мовленні, зокрема вокативні висловлення набувають спонукального значення. Зміст вокативів «приховано» i не розчленовано виражає певну думку-почуття, що нею супроводжується звертання до особи і що імпліцитно наявна в комунікативній ситуації, поза якою немислиме функціонування звертаньречень, що становлять вищою мірою експресивні конструкції (Дудик, 1971: 38).

В основі вокативних висловлень спонукальної модальності лежить звертання. Граматично оформлене звертання не тільки називає адресата мовлення, але й передає інформативно-завершене висловлення, що імпліцитно сконденсовує в собі багатство семантичних відтінків спонукання, які адресат «зчитує» з інтонації та комунікативної ситуації.

Розмежування власне вокативних i спонукальних вокативних висловлень здійснюють на основі комунікативного (контекстного) критерію: - Жоржетто! звернулася лагідно до покоӥвки, щуо саме принесла з холодильника мінералку. - Візьми прибор і сідай зі мною обідати (Г. Тарасюк) - власне-вокативне висловлення; Товаришу гвардії молодший лейтенант! - покликали Черниша десь знизу, з-під насипу. Обернувшись, він побачив бійця свого взводу Гая, високого, сумирного юнака 
Psycholinguistics in a Modern World - 2020. Proceedings of the 15th International Scientific and Practical Conference (Pereiaslav-Khmelnytskyi, 22-23 October, 2020)

(О. Гончар) - вокативне спонукальне висловлення. Обидва висловлення поза комунікативною ситуацією адресат інтерпретуватиме як звертання, i саме комунікативна ситуація «підказує», конкретизує, уточнює зміст висловленого, а також коригує його функційне навантаження, як у другому висловленні - воно виконує фатично-спонукальну функцію: Дмитро прийшов пізно. <..> Bid ранньої весни ночував під оборогом ніби тому, щзо в хаті задуха. - Дмитре, агов, Дмитре! тихо позвала Ільчиха. Чула, як неохоче зіскочив з драбини (І. Вільде).

Фатично-спонукальну функцію вокативні висловлення реалізують незалежно від ступеня соціальної та психологічної близькості між комунікантами: Зупинивсь [Макар] біля стовпа, щзо колись на ньому тріпотіло дивне оголошення. Отут його й побачила Зіна. - Сашка! - вигукнула. Макар озирнувся (Люко Дашвар); У першу мить Ріхтер стояв ні в тих, ні в сих, тоді обвів поглядом натовп, дістав з кобури вальтер і підтюпцем побіг до гурту поліцейських. - Манюус! - закричав Ріхтер. Манжус витягся перед ним (В. Земляк); - Просю покорно за стіл! - запрохувала Огириха. - Лізочко, ти ж таки хазяйка... I де та Зінька ваша, хоч би дитину в молодиці взяла. Зінько! - погукала в кухню. Та вибігла і взяла дитину (А. Головко).

Використовують вокативні висловлення спонукальної модальності також для поновлення контакту. У такій ситуації виконання спонукуваної дії (наприклад, когнітивні ситуації «Повернися», «Говори», «Не йди», «Відповідай» тощо) повністю залежить від адресата спонукання: Олексій (в сторону): Схаменулась! Нехай покортить! (Іде далі). Уляна: Олексію-бо! (Г. Квітка-Основ’яненко).

Вокативні висловлення з транспонованим семантико-синтаксичним значенням використовують і для того, щоб попередити, заборонити, застерегти: Посол. Варвари! 3 ними не мовою і навіть не зброєю... Бичем!!! Як з рабами, як $з$ худобою!.. Бож. Пане посол!.. (О. Коломієць).

Емоційно-експресивне забарвлення вокативних висловлень спонукальної модальності в комунікативному акті посилюють, увиразнюють повтори: ... $i$, трохи, струссивии каміння з душі, йду додому. - Ганно, Ганно, -хтось гукає мене. Роззираюсь (Г. Тарасюк).

«Правильне прочитання» імпліцитного у висловленні можливе за умови володіння однаковими параметрами кодування і декодування мовлення, адже мова кодує сприйняту інформацію (Tillman \& Louwerse, 2018: 159). 


\section{Висновки \\ Conclusions}

Орієнтованість на позитивний результат спонукання передбачає обов'язкове врахування відомих або передбачуваних фонових знань, використання однієї знакової системи кодування і декодування інформації, конвенцій, ситуації мовлення тощо.

Подальші наукові пошуки щодо породження, структурування і сприйняття спонукальних висловлень і трансформованих під впливом мовленнєвої ситуації в спонукальні інших комунікативних типів висловлень відбуватимуться через процеси інтеріоризації та екстеріоризації.

\section{Література \\ References}

Дудик, П.С. (1971). Спонукальні речення і слова речення. Українська мова і літератра в школі, 9, 30-35.

Калмикова, Л.О. (2007). Мовленнєва діяльність як складова предмета психолінгвістики. Гуманітарний вісник Переяслав-Хмельнищького державного педагогічного університету імені Г. Сковороди, 12, 160-164.

Леонтьев, А.Н. (1971). Потребности, мотивы и эмоции. Москва: Изд-во Московского университета.

Tillman, R., \& Louwerse, M. (2018). Estimating Emotions Through Language Statistics and Embodied Cognition. Journal of Psycholinguistic Research, 47(1), 159-167. https://doi.org/10.1007/s10936-017-9522-y 